\title{
MURDER Cooperative Learning Model through Edmodo Toward Mathematics Problem Solving and Motivation of Students
}

\author{
Putu Resya Adi Saputra, Sariyasa, I Nengah Suparta \\ Universitas Pendidikan Ganesha, Jalan Udayana nomor 11 Kec Buleleng, Kab Buleleng, 81116 Bali Indonesia \\ e-mail: resya.adisaputra@gmail.com
}

\begin{abstract}
MURDER cooperative learning model is based on cognitive theory that focuses on how humans acquire, embed, and process what they learn, as well as how the thinking and learning process occurs. This study aims to (1) determine whether the Edmodo-assisted MURDER cooperative learning model has a positive effect on students' problem solving ability and students' motivation in learning mathematics (2) determine whether the Edmodo-assisted MURDER cooperative learning model has a positive effect on students' mathematical problem solving abilities (3) to determine whether the The MURDER cooperative learning model assisted by edmodo has a positive effect on students' motivation to learn mathematics. The research method used is a quasi experiment (quasi experiment) with the research hypothesis testing technique used is MANOVA. The experimental results show that (1) the problem solving ability and motivation to learn mathematics of students who take the Edmodo-assisted MURDER cooperative learning model is significantly better than problem solving ability and motivation to learn mathematics of students who take conventional learning, (2) the mathematics problem solving ability of students who following the Edmodoassisted MURDER cooperative learning model is significantly better than the mathematics problem solving ability of students who take conventional learning, (3) the motivation to learn mathematics of students who take the Edmodo-assisted MURDER cooperative learning model is significantly better than the motivation to learn mathematics of students who take conventional learning .
\end{abstract}

Keywords: MURDER cooperative model, Edmodo, Problem Solving, Learning Motivation.

How to Cite: Saputra, PRA., Sariyasa., \& Suparta, IN. (2020). MURDER Cooperative Learning Model through Edmodo Toward Mathematics Problem Solving and Motivation of Students. International Journal on Emerging Mathematics Education, 4(1), 43-52. http://dx.doi.org/10.12928/ijeme.v4i1.15845

\section{INTRODUCTION}

Mathematics is a basic material that has a very important role and is related closely to everyday life. Mathematics is also stated that to be the creative arts that can be implemented to resolve the problems. Ritu Saxena (2016) stated that mathematics is not only the subject but the algorithm with several different symbols and relationships, in this case, it needs to look at several important aspects in the teaching mathematics such as, students, teachers, curriculum, strategies and techniques.

Learning mathematics should be designed that student is actively involved, both in constructing knowledge and communicate the ideas. It has to be done to achieve the main goal of learning mathematics, as stated in the Minister of Education and Culture No. 64 of 2013 on the Content Standards Subjects Mathematics states that the mathematics courses intended that learner has abilities such as: (1) Showing critical attitude, consistent, accountable, responsive and thorough in solving the problem. (2) Self-confidence, curiosity, and interest in mathematics are formed through the learning experience. (3) Having an objective and open attitude in discussions and can respect to opinions in group 
It shows that problem solving ability is needed in mathematics especially in education field. Problem solving as an effort to discover a way to out from difficulty in order to achieve a goal that needs struggle Polya (1985). Problem solving is considered as "the most level of cognitive complex activity that operates at the same time that is called all the intellectual part of individual including memory, perception, reasoning, conceptualization, language, emotion, motivation, confidence, and ability to control the situation" (Caprioara, 2015).

However, the fact that occurred, Indonesia students have not shown the achievement of mathematics problem solving ability. The quality of education in Indonesia is still low which can be seen based on the results of international research. One of them is PISA (the Program for International Student Assessment) is a program that initiated by the countries belonging OECD (Organization for Economic Cooperationand Development) (OECD, 2018a). PISA assessment subject consists of basic literacy test of reading, math, and science without seeing the national curriculum (Indah, 2019). The Indonesian's achievement remained at lower levels compared to other countries. It is proof by the achievements of Indonesian in 2015 which only ranks $64^{\text {th }}$ from $69^{\text {th }}$ countries (OECD, 2016).

Now the problem that is faced by student is more complex rather than previously the student's ability to solve complex problems. In solving complex problem, student should connect the previous concepts that have been learned to solve the problems. The teacher's role is very important in improving the complex problem-solving ability. Teacher should be able to guide student to achieve a high level of competence through the development of divergent and critical thinking skills, in addition giving student a higher level task who requires student to think differently, criticaly, and creatively.

Besides the problem-solving ability, there is another factor that supports student's low achievement is the lack of student learning motivation. Learning process that treates in the classroom continues should be packed more interesting to make students have an interest in learning and motivation to be better. Student learning motivation is one of important factors during the learning process. "Motivation is encouragement of an effort which is realized to effect someone behavior that make to do something to achieve goal or certain purpose" Purwanto (2011:71). Based on aforementioned statement, it is needed a learning model that can be able to push the enhancement of problem solving ability and learning motivation in teaching mathematics.

Related to the problem, the need of effective and innovative teaching that can increase the ability of student mathematics problem solving optimally. MURDER cooperative learning model based on the cognitive theory that focuses on how human acquires, stores, and processes something that has been studied, and how the process of thinking and learning happened (Santyasa, 2012). There are six steps of cooperative learning model of MURDER type such as in the beginning step is mood, understand, recall, detect, elaborate, and the last step is a review.

MURDER learning model is begun with the mood step where teacher is trying to set the students' mood to focus on learning. The next is understand step means that understanding what is being studied, students read their own material that will be studied and then try to understand and finish the questions or mark the task if it does not understand. Next is recall step means the recalling or repeating the material that already learned. Then the students review the correctness and detect (find) an error or mistake, this is detected as a step. Then, continue to elaborate step means that

IJEME, Vol. 4, No. 1, March 2020, 43-52. 
elaborate knowledge, students are trained to apply their understanding in various situations. The last step is review means to reiterate what has been done.

Based on MURDER learning model steps, there are syntaxs that support students to increase mathematics learning motivation. For example, at the mood step, teacher sets students' mood to be ready to receive material by providing interesting information about the phenomena that occurs in everyday life. This is related to the indicator of motivation is active in learning mathematics that set students' mood before learning is started, student tends to be ready and active in learning mathematics. At understand step student should learn and understand the material that given by teacher. In the detect, elaborate, and review step that relates to the indicator of motivation that is active in learning mathematics and discover for new things related to math.

On MURDER learning model also associated with indicators of problem-solving ability is understand and elaborate step theoretically related to the students' mathematical problem solving ability. On the indicator to understand the problem and make a plan with regard to the understand step where the student has read and understood the material that is provided carefully so when student is given a problem in math, student can make a plan based on mathematical problem solving.

The use of the media also allows the learning process in a far distance that means student is able to learn without a teacher. One of the media that help students to learn independently anywhere and anytime is Edmodo. Edmodo is a collection of exercises to answer the questions and discussions related to learning material that is accessed and answered by students via Internet. The use of Edmodo is based on the development of technology and communication information that potentially affect change of students' characteristics in learning (in Budiyasa, 2013: 4). Online-based test has begun to be used in the UAN (National Exam) so that students are required to master ICT well.

Online learning media such as Edmodo allows anyone without exception for students can answer Edmodo free and real-time, that means that the results can be seen on same day. Learning by using Edmodo more effectively and attract student because of the direct involvement of students in learning activity without limitation of place and time that network connected to the Internet (Santoso, 2009: 58). Based on the results obtained directly on the same day, students are able to reflect the capabilities they have and can motivate students to be more active in learning through the discussion of the questions in Edmodo so that will have an impact on problem solving ability and learning motivation.

In the implementation of MURDER cooperative learning model at understand step, besides the student is guided to be able to understand the problem that is given in the worksheets, the student is also guided to be able to link between the material that is studying with the knowledge that has been owned. In this case, one way to facilitate student to associate the material that is studying with previous knowledge is to convey back the student understanding about the discussion of Edmodo that was answered previously. Therefore, student follows the learning activity that emphasizes verbal skills in constructing the information or ideas that are received, understood, and then communicated, and students can practice to solve various mathematical problem accordance with the material being studied. 


\section{RESEARCH METHOD}

This study was quantitative research with quasi experiment research method with the design of the study used was the Post Test Only Control Group Design. This research was conducted at SMP Negeri 1 Mengwi. Affordable population in this study were 234 students. While the sample of the study was taken as many as 68 students who were divided into 2 (two) classes, namely the experimental class (VIIIF) as many as 34 students and the control class (VIIIE) as many as 34 students.

Data collection methods which were used include the test of problem-solving abilities and the questionnaire method. Provision of tests was given to determine the level of problem-solving ability of students in solving problems after being given treatment. The indicator that can be used in testing problem solving ability is see, plan, do, check. While the questionnaire method was used to determine student learning motivation after being given treatment. Learning motivation are used as the indicator intrinsic motivation and extrinsic motivation. The questionnaire method is also used to determine student responses to learning that has taken place. In addition, the questionnaire was used to improve learning by using Edmodo. The questionnaire was developed in a closed form format using a Likert scale of 1-5 which was analyzed descriptively through a mean score with a maximum score of 5 followed by statistical analysis parametrically with a t-test to determine whether there were differences between the two groups.

\section{RESULTS AND DISCUSSION}

The results of this study were in the form of data scores on mathematical problem-solving and student learning motivation obtained from the results of posttests that have been conducted to the experimental group and the control group. The following was a summary of the data analysis of the results of research into mathematical problem-solving and student motivation.

Table 1. Summary of Descriptive Analysis

\begin{tabular}{llrrr}
\hline & Kelas & Mean & Std. Deviation & $\mathrm{N}$ \\
\hline Pemecahan_Masala & Eksperimen & 64.21 & 12.085 & 33 \\
h & Kontrol & 63.09 & 15.074 & 34 \\
& Total & 63.64 & 13.592 & 67 \\
Motivasi_Belajar & Eksperimen & 66.64 & 7.566 & 33 \\
& Kontrol & 62.06 & 5.882 & 34 \\
& Total & 64.31 & 7.097 & 67 \\
\hline
\end{tabular}

Based on Table 1, it can be seen that the average score of mathematical problemsolving and student motivation in the experimental group was higher than the average score of mathematical problem-solving and student motivation in the control group. 


\section{Testing Prerequisites for Data Analysis}

Table 2. Bivariate Normal Test Analysis Results

\begin{tabular}{llll}
\hline & & $\begin{array}{l}\text { Mahalanobis } \\
\text { Distance }\end{array}$ & Qi \\
\hline \multirow{2}{*}{ Mahalanobis Distance } & Sig. (2-tailed) & $.978^{* *}$ \\
& $\mathrm{~N}$ & 68 & .000 \\
& Pearson Correlation & $.978^{* *}$ & 68 \\
Qi & Sig. (2-tailed) & .000 & \\
& $\mathrm{~N}$ & 68 & 68 \\
\hline
\end{tabular}

Based on Table 2, the results given in the table above, it can be seen that the value of Pearson Correlation Mahalanobis Distance was 0.978 with a significance level of 0.000 less than the specified significance value of 0.05 . Thus, the null hypothesis (H0) was accepted, so it can be concluded that the data come from populations that were normally bivariate in distribution.

Table 3. Homogeneity Test Results for Variance-Covariance Matrix

\begin{tabular}{ll}
\hline Box's M & 4.129 \\
\hline F & 1.331 \\
df1 & 3 \\
df2 & $7.841 \mathrm{E} 5$ \\
Sig. & .262 \\
\hline
\end{tabular}

Based on Table 3, it appears that the value of Box's $M=4.129$ with a significant 0.262 . If a significance level of research of 0.05 was determined, the significance value obtained by 0.262 was greater than 0.05 . Thus, the null hypothesis (H0) was accepted, so it can be said that the matrix of variance between dependent variables were the problem-solving of mathematics and student learning motivation was homogeneous.

\section{Hypothesis test}

Table 4. The result of analysis by MANOVA 
Sig.

\begin{tabular}{|c|c|c|c|c|c|}
\hline Effect & Value & $\mathrm{F}$ & Hypothesis df & Error df & \\
\hline Intercept Pillai's Trace & & & & & .000 \\
\hline & .993 & $4.353 \mathrm{E}^{\mathrm{a}}$ & 2.000 & 64.000 & \\
\hline
\end{tabular}

Wilks' Lambda

.000

$\begin{array}{llll}.007 & 4.353 \mathrm{E} 3^{\mathrm{a}} & 2.000 & 64.000\end{array}$

\begin{tabular}{lllllll} 
& Hotelling's Trace & 136.041 & $4.353 \mathrm{E} 3^{\mathrm{a}}$ & 2.000 & 64.000 & .000 \\
\multirow{3}{*}{ Kelas } & Roy's Largest Root & 136.041 & $4.353 \mathrm{E} 3^{\mathrm{a}}$ & 2.000 & 64.000 & .000 \\
& Pillai's Trace & .114 & $4.124^{\mathrm{a}}$ & 2.000 & 64.000 & .021 \\
& Wilks' Lambda & .886 & $4.124^{\mathrm{a}}$ & 2.000 & 64.000 & .021 \\
& Hotelling's Trace & .129 & $4.124^{\mathrm{a}}$ & 2.000 & 64.000 & .021 \\
& Roy's Largest Root & .129 & $4.124^{\mathrm{a}}$ & 2.000 & 64.000 & .021 \\
\hline
\end{tabular}

Based on Table 4, statistics obtained by Pillai's Trace, Wilks' Lambda, Hotelling's Trace, and Roy's Largest Root are respectively $\mathrm{F}=4.124$, and had a significance of 0.021 less than $0.025\left(\frac{0,05}{2}\right)$. So, $\boldsymbol{H}_{0}$ is rejected. These results stated that solving mathematical problems and students 'motivation to follow MURDER cooperative learning models Assisted by Edmodo was better than solving mathematical problems and students' motivation to follow conventional learning models.

Based on MANOVA test results that have been done, it can be concluded that the problem solving ability and mathematics learning motivation was significantly influenced by the used of learning model. The descriptive analysis and multivariate analysis of variance test (MANOVA), which has been conducted into the basic conclusion that MURDER cooperative learning model through Edmodo provided a good influence on problem solving ability and mathematics learning motivation rather than conventional learning.

The different of mathematical problem solving ability in the experimental class and control class may occurred because mathematics learning with MURDER cooperative learning model MURDER through Edmodo could motivate student on mood step by providing information and phenomena associated with material before continuing learning activity, student was ready and enthusiastic in following study. Motivation and focus of student were very important because it would determine the success in learning. It was based on the research conducted by Darmika (2014) found

IJEME, Vol. 4, No. 1, March 2020, 43-52. 
that students' motivation that was taught by MURDER cooperative learning model was better rather than students' motivation that was taught by conventional learning model.

On the Understand step, student given the opportunity to establish understood independently by reading and grasping the material deeply. The activities carried out by each dyad partner. Dyad can be interpreted as a meeting between two people who communicate orally and writing way. As a technique of learning activity, Dyad can be done by a simple, uncomplicated and can be done by people with each other. The main purpose is to be better for identifying and introducing other people in an intimate and happy situation (Sudjana, 2005). To facilitate the student to understand the concept of learning material, worksheet (LKS) had important role to guide student to find their own concept that was learned so that the concept could be easier to remember by the student and be applied in answering various questions that different from what was discussed in class. In addition, the discussion exercise on Edmodo, made student were able to associate the previous concept material with the concept material that was discussed on that day.

On the recall step, asking student to communicate their understanding of a concept in groups with each pair dyad will be trained the students' problem-solving ability. Mathematical problem solving ability provided the opportunity for student to develop idea through language and symbols to solve a mathematical problem. On the other word the problem situation was interesting, challenging, and contextual could inspire student to develop creative idea either individual or group to ask or solve a math problem with varying degrees of complexity.

Next, on detect step, other couples of dyad also had the opportunity to present the idea or if there was a discrepancy of ideas, which can create the courage for asking and critical thinking. This discussion will involve student to be more active because each member of the group had the same responsibility in solving the problems that was given on the worksheet (LKS). Communicating the material with the words was a way of students to understand the material. A good understanding of the material could give a mathematical problem solving ability was good also. A good understanding needed to be applied for solving of a mathematics problem, so it was important for student tried to elaborate understanding of a concept.

On elaboration step gave an opportunity to student how students used their knowledge to give some examples or applications. Student could repeat the work of other problems with the same step that could help student to remember the material that being studied. On elaboration step, when student had difficulty for solving mathematics student problem is given help questions to facilitate the student to understand the question that was asked. Furthermore, the discussion exercise on Edmodo discussed previously could be a reflection to understand the issues that were discussed at the meeting that emphasized the various types of questions that had been finished on Edmodo. Elaboration that oriented understanding of information processing that emphasized on improving the ability of learners in processing information. Therefore, how learner caught the existing stimulus and stored the information that is meaningful to short-term memory and long term memory and then poured into a post so that the information received could be seen again. At this step also emphasized the aspects of learners' ability to solve problem, develop concepts, and emphasize creative thinking productive (Arifuddin, 2010: 21).

The findings of recall, detect, and elaborate step proved that the problem of low interest in mathematics learning, student was less accustomed to think creatively 
in solving mathematical problems, and the notion of mathematics was learning to memorize, and boring had been resolved. The findings were reinforced by the argument of Santyasa (2012) which stated that the recall measures, detect, and can reinforce learning elaborate because the couple dyad in the group verbally express, explain, expand and record the main ideas of a given problem. In this case, information processing skills were preferred.

On the review step, student was trained to deliver the results of group discussion. Students did a review of the results of its work and transmit on another couple in the group and made their conclusions. On this stage, information was exchanged between one group with another group in a class with one of the dyad of certain groups were assigned at random to present the group's work. Each pair Dyad corrected their work so that there was no interaction between groups. This interaction will be obtained from the settlement of the problem or whole problems that given. Student with teacher guidance summarized the material that had been discussed at that time, evaluated again and made learning conclusion that wrote a note which was easier the understanding of a concept.

MURDER cooperative learning model through Edmodo could assist student in understanding, developing, implementing, and know the process of solving mathematical problems. Student who was not usually active in practicing problems of mathematical problem would appear the interest to do it because when they found the difficulties in solving mathematical problems, student had the opportunity to learn through discussion questions that was provided. Furthermore, teacher could also see the extent the student understanding to the material being studied so that teacher could emphasize the part that had not been understood by student. Thus the learning activities will be more effective. This is based on the research conducted by I. M Budiyasa (2013) stated that online learning material and online alternative assessment was effective to improve the ability of problem solving in teaching science of eighth-grade second semester junior high school student. According to Budiyasa (2013), an alternative online test designed to establish the readiness of the student independently, explore and develop the potential of their self. The used of exercise test on Edmodo had benefit for increasing sportsmanship in competition, so that the learning process could not be ignored by the student if they wanted to obtain a good problem-solving ability.

In the experimental class was applied MURDER learning model through Edmodo showed that student always felt excited when starting the learning activity because of apperception that contained about the use and benefit of learning materials were discussed. Student was braver to express their opinions during group discussion. Through the elaboration step student was able to answer the problem was different from the questions that was provided on LKS (worksheet) because they got a lot more discussion on current issues and answered practice test on Edmodo. Furthermore, the students' independence in facing the problem of mathematics to be increased, it was shown that student would try to answer a hard question firstly, however if they had not been able to get results, then they would ask other people. Students were easier to remember the concept of learning material because they were directly involved in the process of discovery of the concept itself through the answering the LKS (worksheet). Through Edmodo application, student was easier to understand the learning material because they can learn from the discussion on Edmodo. This showed that in general the contribution of MURDER cooperative learning model through Edmodo had positive effect on mathematics student problem solving ability. It was based on the

IJEME, Vol. 4, No. 1, March 2020, 43-52. 
research by Rici Elnanda (2014) found that the ability of understanding mathematics concepts was taught by MURDER collaborative learning model was higher rather than student was taught by conventional learning.

\section{CONCLUSION}

From the results of data processing, the following conclusions can be drawn: (1) Based on data analysis and hypothesis testing that has been done, it appears that the problem-solving ability and motivation of mathematics learning of students who follow the MURDER cooperative learning model Assisted by Edmodo is better than the ability to solve problems and motivation learning mathematics students who follow conventional learning models. In this regard, it can be concluded that the MURDER cooperative learning model assisted by Edmodo is better than the conventional learning model. (2) MURDER cooperative learning model Assisted by Edmodo contributes positively to students 'problem-solving abilities and students' motivation to learn mathematics; a. students become more enthusiastic in participating in learning activities; $b$. students are able to understand the problems given to the worksheet; c. students are trained to communicate their understanding of a concept in group discussions; d. students are easier to remember concepts from learning material; e. Students have the opportunity to apply their understanding of mathematical concepts as well as independent learning by solving some problems in practice tests on Edmodo.

\section{REFERENCES}

Ariningsih, N. M., Suami, N. K., \& Suranata, K. (2013). Pengaruh Model Pembelajaran Kooperatif Tipe MURDER Berbantuan LKS Terhadap Hasil Belajar IPA Siswa Kelas V SD Gugus IV Kecamatan Tabanan. Jurnal [Online]. Jurusan PGSD. FIP. Universitas Pendidikan Ganesha.

Balasubramanian, K., Jaykumar, V., \& Fukey, L. N. (2014). A Study on "Student Preference towards the Use of Edmodo as a Learning Platform to Create Responsible Learning Environment". Procedia-Social and Behavioral Sciences, $144,416-422$.

Benning, I. (2018). Using Technology in Mathematics: Professional Development for Teachers. Otago: University of Otago Press.

Darmika, N. K., Suma, K., \& Suastra, I. W. (2014). Pengaruh Model Pembelajaran Kooperatif MURDER Terhadap Motivasi Belajar dan Prestasi Belajar IPA Siswa SMP. e-Journal Program Pascasarjana Universitas Pendidikan Ganesha Program Studi IPA, 4.

Departemen Pendidikan Nasional. (2013). Permendiknas Nomor 64 tentang Standar Isi Mata Pelajaran Matematika

Elnanda, Rici. 2014. Pengaruh Model Pembelajaran Collaborative MURDER Terhadap Kemampuan Pemahaman Konsep Matematika Siswa. Thesis. Jakarta: UIN Syarif Hidayatullah Jakarta

Fung, M.G., \& Roland, L. (2004). Writing, reading, and assessing in an elementary problem solving class. In problems, resources, and issues in mathematics undergraduate studies. Problems, Resources, and Issues in Mathematics Undergraduate Studies, 14(4), 289-302.

Indah, P. (2019). Efek Program PISA Terhadap Kurikulum di Indonesia. Jurnal Pendidikan dan Kebudayaan, 4(1), 51-71.

Juniantari, M., Sariyasa., \& Sadra, I. W. (2015). Pengembangan Perangkat Pembelajaran 
Matematika Realistik Bagi Siswa SMP Kelas VII dengan Seting Model Kooperatif MURDER". Proceedings Seminar Nasional FMIPA UNDIKSHA V Tahun 2015. 178183.

Mertasari, N. M. S. (2003). Pengaruh Model Tes Terhadap Motivasi Belajar dengan Mempertimbangkan Kesukaran Tes (Eksperimen Pada Sekolah Lanjutan Tingkat Pertama di Kota Singaraja). Thesis. Singaraja: IKIP Negeri Singaraja (UNDIKSHA)

OECD. (2016). Country Note: Indonesia. Program for international student assessment (PISA) Result from PISA 2015.

OECD. (2018a). PISA Result in Focus.

Richmond, G., \& Striley, J. (1996). Making Meaning in Classrooms: Social Processes in Small-Group Discourse and Scientific Knowledge Building. Journal of Research in Science Teaching, 33(8), 839-858.

Polya, G. (1985). How to Solve It: A new aspect of mathematics method (2 ed). Princeton: Princeton University Press.

Ruseffendi, E.T. (1991). Pengantar kepada membantu Guru Mengembangkan Kompetensinya dalam Pengajaran Matematika untuk Meningkatkan CBSA (Cetakan Kedua). Bandung: Tarsito.

Santyasa, I W. (2012). Pembelajaran Inovatif. Singaraja: Undiksha

Sardiman, A.M. (2011). Interaksi dan Motivasi Belajar Mengajar. Jakarta: Rajawali.

Sugiyono. (2012). Metode Penelitian Pendidikan. Bandung: Alfabeta.

Saxena, R. (2016). Teaching Mathematical Modeling in Mathematics Education. Journal of Education and Practice, 7(11), 34-44. 